\title{
NUMBERS OF MORTALITY IN THE STATE OF MARANHÃO, BRAZIL
}

\author{
João Marcelo da Silva Abreu', Maira Rodrigues', Rafael Sousa Pinto \\ 1 Programa de Pós-graduação BIONORTE - Rede de Biodiversidade e Biotecnologia da Amazônia Legal, Federal \\ University of Maranhão, UFMA, São Luís/MA, Brazil. \\ ${ }^{*}$ Corresponding author: joaabreu@hotmail.com
}

Received: Jun. 02, 2017 - Accepted: Aug. 12, 2017

http://dx.doi.org/10.22615/2526-1746-jgm-2.2-6826

\begin{abstract}
Death is defined by the World Health Organization as the cessation of vital signs at any time after birth, with no possibility of resuscitation. The objective of this study was to analyze the temporal dynamics of mortality in the State of Maranhão using data from the Mortality Information System (SIM) of the National Department of Health. For this, it was used information on the mortality rate of all municipalities in the State in the years 2000, 2010 and 2014 . Data were initially analyzed through descriptive statistics to determine the main statistical moments. The statistical analysis demonstrated that data presented high coefficient of variation value and did not show normal frequency distribution. Through the maps generated it is possible to verify that only the city of São Luís had more than 1000 deaths in the three years analyzed. In addition to the growth in the total number of deaths in the state, accompanying the population increase.
\end{abstract}

Key words: mortality information system, São Luís, population growth.

\section{NÚMEROS DE MORTALIDADE NO ESTADO DE MARANHÃO, BRASIL}

RESUMO: A morte é definida, pela Organização Mundial da Saúde, como a cessação dos sinais vitais em um momento qualquer depois do nascimento com vida, sem possibilidade de ressuscitação. Dessa forma, o objetivo deste artigo foi analisar a dinâmica temporal da mortalidade no Estado do Maranhão utilizando os dados do Sistema de Informação sobre Mortalidade (SIM) do Ministério da Saúde. Para isso, foram utilizadas informações sobre a taxa de mortalidade de todos os municípios do estado nos anos de 2000, 2010 e 2014. Os dados foram inicialmente analisados por meio da estatística descritiva para determinar os principais momentos estatísticos. A análise estatística demonstrou que os dados possuem altos valores de coeficiente de variação e não possuem distribuição normal. Através dos mapas gerados é possível verificar que somente a cidade de São Luís teve mais de 1000 óbitos nos três anos analisados. Além do crescimento do número total de óbitos no estado, acompanhando o aumento populacional.

Palavras-chave: sistema de informação sobre mortalidade, São Luís, crescimento populacional. 


\section{INTRODUCTION}

Death is defined by the World Health Organization as the cessation of vital signs at any time after birth, with no possibility of resuscitation (OMS, 1995). The definition of causes mortis implies several important meanings, either in the justification of governmental actions, against the national or regional epidemiological profile, outlining public policies for the reduction of mortality and health promotion; at the individual level, attends to legal developments, social security needs and rights, or doubts of bereaved relatives (CARDOSO, 2007).

The study of mortality that is made possible through the Declaration of Death is important for two factors: the first for distinguish the epidemiological profile of a population, since, according to BRAGA (2014), the study of its records helps the researchers in the elaboration of the epidemiological picture, and the second to contribute to the statistical analysis of causes of death (KOTABAGI et al., 2004).

In Brazil, information on mortality comes from an information system conceived and implemented in the country about thirty years ago (Mortality Information System SIM), which has as its basic document the Declaration of Death filled out by the doctor. The form model it is standardized throughout the country, as is the flow of information (LAURENTI et al., 2006; MELLO JORGE et al., 2007).

Death declarations are collected by the Municipal or State Health Departments in hospitals and registry offices, and then coded and transcribed into a computerized system. The codification and selection of causes of death is in accordance with the provisions of the World Health Organization, through the International Classification of Diseases, currently in its 10th Revision (OMS, 1995).

According to the Pan American Health Organization (2016), Maranhão mortality data indicate that the State is affected by the triple burden of diseases: transmissible, nontransmissible and resulting from urban violence and accidents. The objective of this study was to analyze the temporal dynamics of mortality in the state of Maranhão using data from the Mortality Information System (SIM) of the National Department of Health in the years 2000, 2010 and 2014.

\section{MATERIAL AND METHODS}

The tenth most populous state in Brazil, Maranhão has approximately 6.9 million inhabitants (IBGE, 2016a). Located in the northeast region of the country, the state is bordered to the north by the Atlantic Ocean, below the Equator line and southeast of the Amazon River basin (BRITANNICA ACADEMIC, 2017).

For this study, it was used information of the mortality rate of all 217 municipalities in the State of Maranhão in 2000, 2010 and 2014, made available by the Ministério da Saúde through the Mortality Information System (SIM) (Ministério da Saúde, 2015).

Data were initially analyzed by means of descriptive statistics to determine the main statistical moments (minimum and maximum value, mean, median, variance, standard deviation, coefficient of variation, skew, kurtosis and Kolmogorov-Smirnov test at $0.01 \%$ probability, in software Surfer v.13 (Golden Software, 2016). 
The Kolmogorov-Smirnov normality test was used to evaluate the frequency distribution of the data. The coefficient of variation (CV) values were used to determine the variability of the data according to the classification of PIMENTEL-GOMES and GARCIA (2002), being considered low $(C V<10 \%)$, medium $(10 \%<C V<20 \%)$, high $(20 \%<C V<30 \%)$ and very high ( $C V>30 \%)$.

Maps were generated with mortality data from each municipality for better visualization of the information. A linear correlation ( $r$ ) was performed between the average number of deaths in the municipalities that make up the metropolitan region of São Luís Island and the five municipalities with the highest Gross Domestic Product (GDP) in the state (IBGE, $2016 \mathrm{~b})$, with the values corresponding to the number of inhabitants of these municipalities, to verify the occurrence of correlation between variables.

\section{RESULTS AND DISCUSSION}

From the analysis of the descriptive statistics (Table 1) we noticed a high variability of the data due to the very high coefficient of variation value ( $C V>30 \%)$, since it can also be confirmed by the large difference between the minimum and maximum values. On the other hand, it is observed that the data do not show normal frequency distribution according to the Kolmogorov-Smirnov test at $0.01 \%$ probability.

Through the maps generated with data from all the municipalities of the State of Maranhão for the years studied (Figure 1), it is possible to verify that only the city of São Luís had more than 1000 deaths in the three years analyzed and that the city of Imperatriz also demonstrated more than 1000 deaths in two years (2010 and 2014). Which correspond exactly to the two most populous cities of the state (IBGE, 2016a).

It is possible to notice a growth in the number of municipalities with more than 100 deaths in the state that in 2000 did not surpass 13\% and in 2010 and 2014 passed to $26 \%$ and $34 \%$, respectively. In addition to the growth in the total number of deaths in the state that was 16041 in 2000, 26091 in 2010 and 32101 in 2014, doubling over a period of 14 years. This information shows a tendency to follow the population growth, the bigger the population size, the greater the number of deaths.

This tendency is confirmed by analyzing only the municipalities of the metropolitan region corresponding to São Luís Island (Figure 2), where we see that the number of deaths is directly related to the population size of each city. This fact also occurs when we check only the five cities with the highest Gross Domestic Product (GDP) in the state (Figure 3). Data confirmed by the values of the linear correlation coefficient, which were very strong for the two analyzes, being 0.998981 and 0.998493 , respectively. 
Table 1. Statistical parameters for the number of deaths in the municipalities of the State of Maranhão in the years 2000,2010 and 2014.

\begin{tabular}{|c|c|c|c|}
\hline & 2000 & 2010 & 2014 \\
\hline Number of values & 217 & 217 & 217 \\
\hline Sum & 16023 & 26069 & 32048 \\
\hline Minimum & 1 & 6 & 16 \\
\hline Maximum & 4009 & 4942 & 5945 \\
\hline Mean & 73.839 & 120.134 & 147.687 \\
\hline Variance & 82294.821 & 127866.079 & 184272.235 \\
\hline Standard deviation & 286.871 & 357.584 & 429.269 \\
\hline Coefficient of variation (\%) & 388.51 & 297.655 & 290.662 \\
\hline Skew & 12.249 & 11.712 & 11.744 \\
\hline Kurtosis & 165.948 & 155.053 & 155.917 \\
\hline Kolmogorov-Smirnov stat & $0.398 \mathrm{Ln}$ & $0.375 \mathrm{Ln}$ & 0379Ln \\
\hline
\end{tabular}
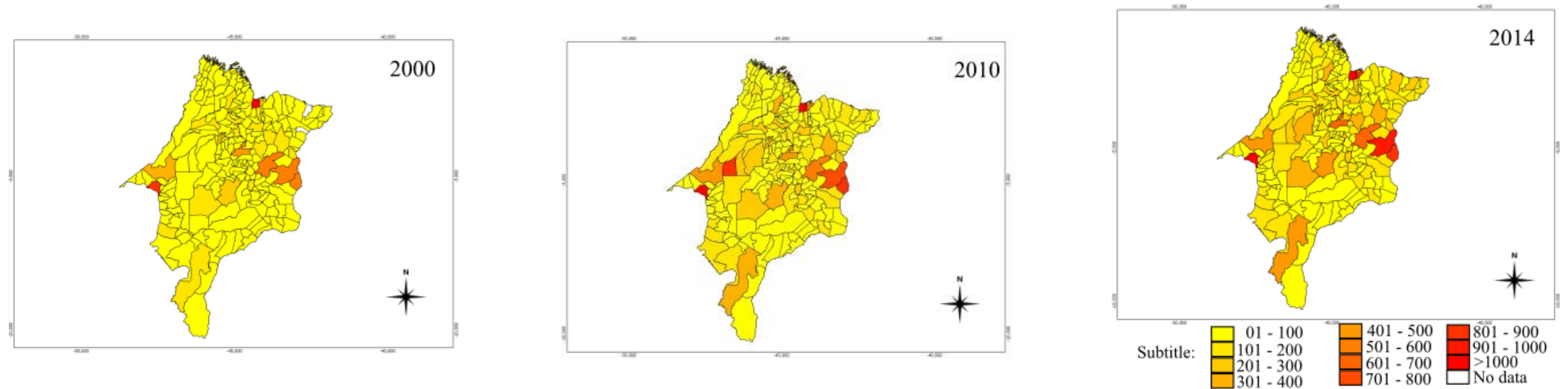

Figure 1. Map of the number of deaths per municipality in the State of Maranhão in the years 2000, 2010 and 2014 
The results obtained demonstrate the agreement with the literature on the higher the population the greater the number of deaths, which is mainly due to the effects of uncontrolled and poorly planned urbanization in some cities, leading to an increase in violence, as well as an increase some diseases caused mainly by deficits in basic sanitation, garbage collection and the provision of a sufficient number of hospitals (GAWRYSZEWSKI et al., 2004; COSTA e MARCOPITO, 2008; LIMA et al., 2013; LAURENTI et al., 2013).

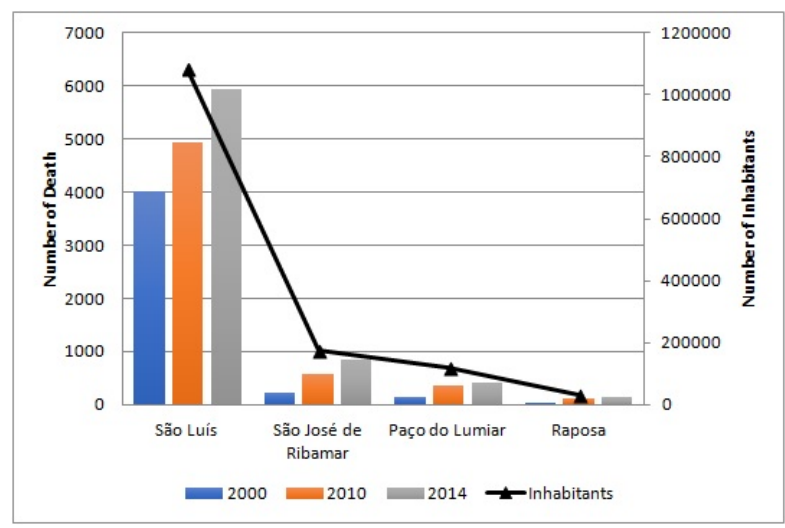

Figure 2. Number of deaths in the cities that make up the metropolitan region of São Luís Island.

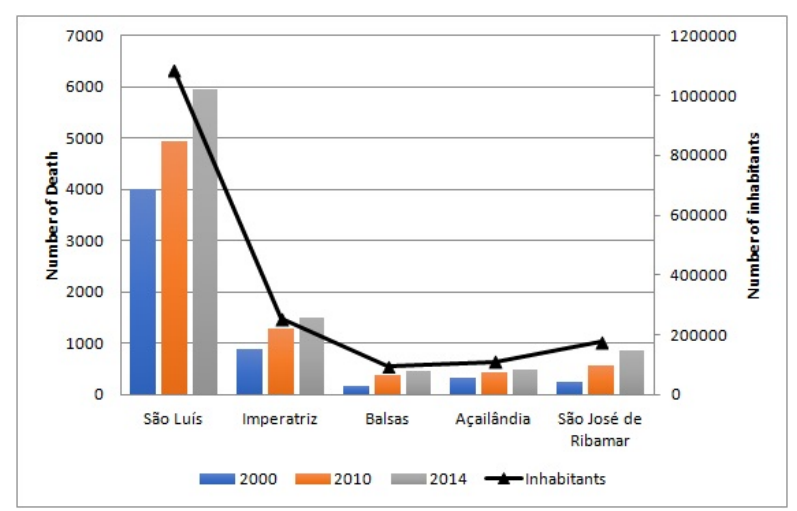

Figure 3. Number of deaths in the cities with the highest GDP in the state of Maranhão.

Maranhão is the tenth most populous state in Brazil, with more than 6.9 million inhabitants (IBGE, 2016a). But it has one of the lowest expectations of life in the country, which is 70.2 years, while the national average is 74.5 years, and this is due to the lower human development indices of the municipalities of Maranhão (PNUD, 2016). The reduction of mortality in Maranhão and, consequently, an increase in life expectancy is due to the improvement of the population's living conditions, prevention and rapid access to health services.

\section{CONCLUSIONS}

The number of deaths in Maranhão doubled over a period of 14 years (2000 to 2014), and by the descriptive analysis of the number of deaths in the 217 municipalities, the data did not have a normal distribution. The most populous cities of the state, São Luís and Imperatriz, had the highest number of deaths; this same proportion (inhabitants $x$ deaths) occurs in the cities with the highest GDP and cities that make up the metropolitan region of São Luís Island.

However, although the number of deaths is related to population size, it is possible that the causes of death and the mortality profile vary according to the municipality, exposing regional problems that affect the quality of life of citizens.

\section{REFEDRENCES}

Berquó. E. S. 1980. Fatores estatístico e dinâmicos (Mortalidade e Fecundidade). p. 22-85. In: Santos, J.F.; Levy, M.S.F.; Szmrecsányi, T. Org(s). 1980. Dinâmica da população: teoria, métodos e técnicas de análise. T.A. Queiróz, São Paulo, SP, Brasil. 
Braga, J.S. 2014. Qualidade das Estatísticas de óbitos no semiárido brasileiro: relação com as condições de vida. Monografia (Trabalho de conclusão de curso). Universidade Federal da Paraíba, João Pessoa, PB, Brasil.

Brittanica Academic. (2017). Maranhão. Acesso em: http://academic-ebbritannica.ez14.periodicos.capes.gov.br/levels /collegiate/article/Maranh\%C3\%A3o/50737

Cardoso, A.B.C. 2007. Serviços de verificação de óbitos: características e contribuições para o esclarecimento de causas de morte. Dissertação (Mestrado). Universidade Federal do Paraná, Curitiba, PR, Brasil.

Costa, M.R.; Marcopito, L.F. 2008. Mortalidade por causas mal definidas, Brasil, 1979-2002, e um modelo preditivo para idade. Cad. Saúde Pública, v. 24, n. 5, p. 10011012.

Gawryszewski, V.P.; Koizumi, M.S.; Mello Jorge, M.H.P. 2004. As causas externas no Brasil no ano 2000: comparando a mortalidade e a morbidade. Cad. Saúde Pública, v. 20, n. 4, p. 995-1003.

Golden Software. 2016. Surfer: Full User's Guide (Version 13). EEUU: Golden Software, $679 \mathrm{p}$.

IBGE - Instituto Brasileiro de Geografia e Estatística. 2016a. Estimativas da população residente no Brasil e Unidades da Federação com data de referência em 1 으 de julho de 2016. Rio de Janeiro, RJ, Brasil.

IBGE - Instituto Brasileiro de Geografia e Estatística. 2016b. Produto interno bruto dos municípios: 2010-2014. Rio de Janeiro, RJ, Brasil.

Kotabagi, R. B.; Chaturvedi, R. K.; Banerjee, A. 2004. Medical certification of cause of death. Med J Armed Forces India, v. 60, n. 3, p. 261272.
Laurenti, R.; Mello Jorge, M.H.P.; Gotlieb, S.L.D. eds. 2006. O Sistema de Informações sobre Mortalidade: passado, presente e futuro. Centro Brasileiro de Classificação de Doenças, São Paulo, SP, Brasil. 1 ed.

Laurenti, R.; Mello Jorge, M.H.P.; Gotlieb, S.L.D. 2013. Estatísticas de mortalidade e seus usos. R. Eletr. de Com. Inf. Inov. Saúde, v. 7, n. 2.

Lima, R.H. da S.; Amorim, R. T.; Martins, V. de A.; Rodrigues, L. dos S.; Lucena, R. F. 2013. Mortalidade por causas externas no estado do Maranhão, Brasil: Tendências de 2001 a 2010. Rev Pesq Saúde, v. 14, n. 2, p. 96-100.

Mello Jorge, M.H.P.; Laurenti R.; Gotlieb, S.L.D. 2007. Análise da qualidade das estatísticas vitais brasileiras: a experiência da implantação do SIM e do SINASC. Revista Ciência \& Saúde Coletiva, v. 12, n. 3, p. 64354.

Ministério da Saúde. 2015. Saúde Brasil 2014: Uma análise da situação de saúde e das causas externas. Fundação Nacional de Saúde, Brasília, DF, Brasil.

OMS - Organização Mundial da Saúde. 1995. Classificação Estatística Internacional de Doenças e Problemas Relacionados à Saúde. 10a Revisão (Vols. 1 e 2). Centro Brasileiro de Classificação de Doenças, São Paulo, SP, Brasil.

Organização Pan-Americana da Saúde. 2016. Atenção à saúde em Municípios de Pequeno Porte do Maranhão. Efeitos do Programa mais Médicos. OPAS, Brasília, DF, Brasil.

Pimentel-Gomes, F; Garcia C.H. eds. 2002. Estatística aplicada a experimentos agronômicos e florestais: Exposição com exemplos e orientações para uso de aplicativos. FAEALQ, Piracicaba, SP, Brasil.

PNUD - Programa das Nações Unidas para o Desenvolvimento. 2016. Radar IDHM. Brasília, DF, Brasil. 